\title{
Black-tailed Jackrabbit Diet and Density on Rangeland and Near Agricultural Crops
}

\author{
KATHLEEN A. FAGERSTONE, G. KEITH LAVOIE, AND RICHARD E. GRIFFITH, JR.,
}

\begin{abstract}
Black-tailed jackrabbit diets and densities were compared between rangeland and cultivated areas in southern Idaho to determine how heavily jackrabbits rely on crops for spring and summer food. Jackrabbit densities were significantly higher near cultivated crops than on the isolated rangeland. Where barley and crested wheatgrass plants were available to jackrabbits, they were preferred foods and made up a large part of the spring and summer diet. As potato plants were not a highly preferred food, crop, damage by jackrabbits could probably be reduced by planting potatoes in a buffer strip between rangeland and preferred grain crops. Plant phenology was a major factor in determining food preferences of jackrabbits collected on rangeland. In the spring, $85 \%$ of rangeland diet consisted of grass. However, in early summer, grasses and forbs were eaten in equal amounts and by late summer, $71 \%$ of the diet was comprised of forbs and shrubs.
\end{abstract}

Jackrabbits damage a wide variety of agricultural crops. Vorhies and Taylor (1933) reported that orchard and ornamental trees, alfalfa, and young cotton were the most frequently damaged crops in Arizona. In California, alfalfa, barley, forage crops, vineyards, and young orchards were damaged in early fall or when rabbit populations were high (Nelson 1930; Orr 1940). Janson (1946) reported that jackrabbits in Utah consumed considerable quantities of alfalfa, grain, and vegetable crops. Sparks (1968) and Flinders and Hansen (1972) found that alfalfa was important as a winter food. Other crops consumed by jackrabbits include cabbage, clover, soybeans, root crops, and tomatoes (Lechleitner 1958; Schwartz and Schwartz 1959; and Lindt 1965). Answers to a 1964-1965 questionnaire sent to county agents in the 17 western states (Hegdal 1974, unpublished) indicated that jackrabbits annually cause approximately $\$ 3$ million worth of damage to agricultural crops. Jackrabbit movements in response to food supplies have been reported by Currie and Goodwin (1966) and Vorhies and Taylor (1933). Bronson and Tiemeier (1958) found that drouth and overgrazing in the Kansas sandhills caused jackrabbits to move into cultivated areas in search of food. Carter (1939) and Brown (1947) both felt that jackrabbit numbers increased in the early 1900's because of crop cultivation.

Feeding patterns and preferences of black-tailed jackrabbits have been well documented by Vorhies and Taylor (1933), Fautin (1946), Schwartz and Schwartz (1959), Currie and Goodwin (1966), Hayden (1966), and Flinders and Hansen (1972). However, most of these studies concentrated on rangeland diets. Little work has been done to determine how heavily black-tailed jackrabbits rely on agricultural

The authors are all wildlife biologists at the Denver Wildlife Research Center, U.S Fish and Wildlife Service, Building 16, Denver Federal Center, Denver, Colorado 80225 .

Thanks are extended to John Keith, Farrel Branson, James Scott, and Hansford Shacklette of the U.S. Geological Survey for their help in the identification of our reference plant collection.

Manuscript received January 22, 1979 crops for food and whether they are drawn to crop areas. Therefore, in this study, we compared black-tailed jackrabbit diets and densities between range and croplands.

We conducted the study in 1972-1973 in Owyhee and Twin Falls counties of Idaho. This area is mostly rangeland with some dry land and irrigation farming. The rangeland is dominated by big sagebrush (Artemisia tridentata), cheatgrass brome (Bromus tectorum), and bluegrass (Poa secunda). Bottlebrush squirreltail (Sitanion hystrix), Indianwheat (Plantago sp.), and tansymustard (Descurainia pinnata) are also common.

\section{Methods}

We chose four agricultural crops for the study: potatoes (Solanum tuberosum), crested wheatgrass plantings (Agropyron desertorum), barley (Hordeum vulgare), and mixed barley and alfalfa (Medicago sativa). Each of these crops was bordered on one edge by rangeland. To avoid possible influence of crops on jackrabbit diets or densities, we chose a rangeland site several kilometers away from the nearest crop. On each area, we censused jackrabbit populations, measured plant composition, and collected jackrabbits for food preference determinations.

We counted jackrabbits once a month on the five areas by a road count similar to that used by Tiemeier (1965) and Flinders and Hansen (1972). The count was conducted between 2000 and 2400 hours by driving $8 \mathrm{~km}$ per hour along a $3.2 \mathrm{~km}$ section of road bordering the crop and counting the number of jackrabbits seen crossing the road within the high headlight beam. Counts were made on three consecutive nights, with the highest number of jackrabbits counted used as the monthly density estimate.

To aid in interpreting food preference results, we measured plant composition in April, June, and August at each crop area and on the rangeland. Eight randomly located line transects were established at each crop site (four on the crop and four on the adjacent rangeland) and on the rangeland site. At 3-m intervals along each transect, we read 50 points, using the step-poing method described by Evans and Love (1957).

We determined diet by analyzing stomach contents of up to 12 jackrabbits shot at each area in April, June, and August. Jackrabbits were shot between 2000 and 2400 hours during their normal feeding period. We had planned to collect jackrabbits through the fall and winter, but this was prevented by a sudden decline in the jackrabbit population.

Jackrabbit stomachs were frozen until a sample of stomach contents could be stained and two microscope slides prepared (Fagerstone et al. 1977). Plant fragments in jackrabbit stomachs were identified by comparing their epidermal characteristics with those of identified plant species. Plant species composition was determined for each stomach by examining 10 microscope fields at 100 magnification. A $10 \times 10 \mathrm{~mm}$ eyepiece grid was used to determine the percentage by area of each species present in the diet (Fagerstone et al. 1977). The similarity between jackrabbit diet and plant composition of the habitat was calculated using an index for coefficient of similarity (Oosting 1956, p. 77). The similarity index 


$$
(S I)=2 \sum_{i=1}^{n} \min \left(D_{i}, H_{i}\right) / \sum_{i=1}^{n}\left(D_{i}+H_{i}\right)
$$

where $D_{\mathrm{i}}$ is the percentage of the ith species in the jackrabbit diet and $H_{\mathrm{i}}$ is the percentage of the $i t h$ species in the habitat.

Preference indexes were calculated for each animal as: $(\%$ of crop in diet) $\div$ (percentage of crop in habitat). A value of one indicates that jackrabbits are choosing that food in the same proportion as it occurred in the habitat. Values greater than one indicate that jackrabbits are selecting for that food.

Jackrabbit density data were analyzed for differences between crops by one-way analysis of variance. All other data were analyzed for month and crop differences by two-way analysis of variance. Duncan's multiple range test (Kramer 1956) was used to separate means that differed significantly.

\section{Results}

\section{Density}

Our road counts showed that agricultural crops served as concentration areas for jackrabbits during the growing season (Fig. 1). The highest density of jackrabbits occurred in July on the mixed barley and alfalfa field, where we counted 37 jackrabbits / km of field edge; this area averaged 11 jackrabbits/ $\mathrm{km}$ for the entire year. The crested wheatgrass area had the second highest jackrabbit density ( a peak of 20

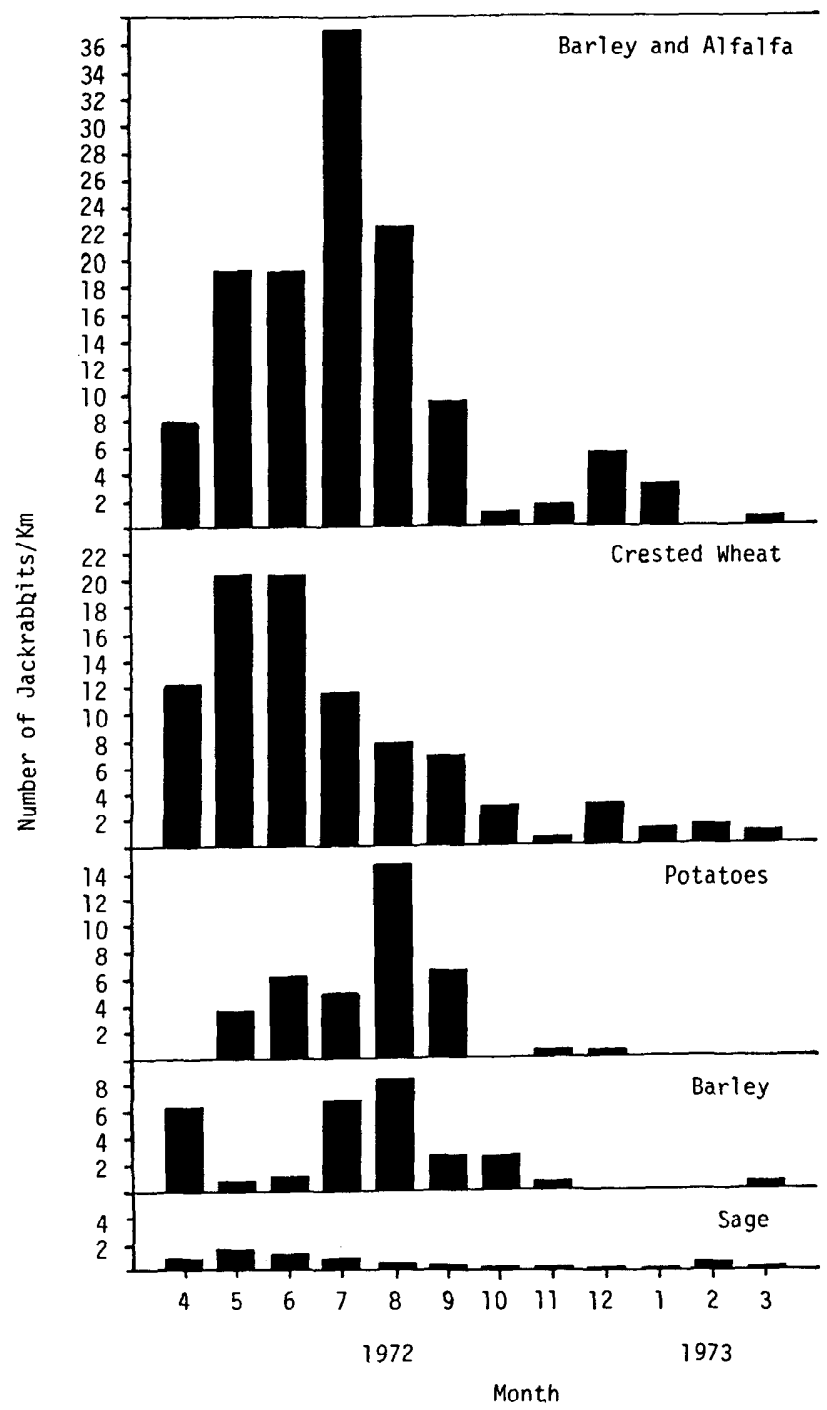

Fig. 1. Black-tailed jackrabbits counted per kilometer of habitat border on 5 study areas. rabbits in May and June and an average of $7 / \mathrm{km})$. The potato area averaged $4 / \mathrm{km}$ and the barley area averaged $2.5 / \mathrm{km}$. The rangeland showed consistently low densities throughout the study, averaging only 0.6 rabbits $/ \mathrm{km}$. Jackrabbit density on the rangeland was significantly less than on all of the crop areas except the barley area. There were no significant differences in density among any of the other crop areas. In all areas, jackrabbit density decreased at the end of the growing season. At this time the jackrabbit population was beginning its decline.

\section{Diet}

Jackrabbits collected near crested wheatgrass and barley fields relied heavily on those crops for spring and summer food (Table 1). They ate an average of $23 \%$ crested wheatgrass in April, $70 \%$ in June, and $80 \%$ in August. Crested wheatgrass occurred in all jackrabbit stomachs collected on that area. It was a highly preferred food, with preference indexes of 4.4 in April, 4.2 in June, and 6.5 in August. Wheatgrass leaves were preferred in April (seeds were not yet available), leaves and seeds in June, and mostly seeds in August. Those rabbits collected near barley fields ate an average of $32 \%$ barley in April, $61 \%$ in June, and $23 \%$ in August. In June, when barley utilization was highest, jackrabbits were eating mostly green leaf material; utilization declined in August as the barley neared harvest. Barley utilization was higher on the mixed barley and alfalfa area than on the barley area. Jackrabbits showed a preference for barley (Table 1) on the mixed barley and alfalfa area bud did not show a preference on the barley area. We do not know the reason for the differences between these two areas. Neither potatoes nor alfalfa made up a large part of the diet; potato leaves made up $19 \%$ of the diet in June and $17 \%$ in August. Alfalfa was important only in August, when it made up $17 \%$ of the diet.

Altogether, 32 plant species were identified in the jackrabbit diet on the five areas studied. Jackrabbits collected on rangeland ate 25 plant species, including nine species of grasses and 16 species of forbs (Table 2). Phenology played a large role in food selection on the rangeland. Grasses were preferred in the spring and made up $85 \%$ of the diet (Fig. 2). Favorites were the leaves of cheatgrass brome and leaves and seeds of early maturing bluegrass and six-weeks fescue (Festuca octoflora). By June, the bluegrass and six-weeks fescue had dried and were no longer preferred foods. At this time, jackrabbits ate half grasses and half shrubs and forbs, with cheatgrass brome, cryptantha (Cryptantha sp.), big sagebrush, and bottlebrush squirreltail comprising $77 \%$ of the diet. In August, jackrabbit preference switched to latematuring forbs and shrubs including big sagebrush, pigweed (Amaranthus graecizans), Russian thistle (Salsola kali), tansymustard, and rabbitbrush (Chrysothamnus nauseosus). The flowers of Russian thistle sometimes occurred in stomachs in large quantities. Insect parts were eaten infrequently and were probably an accidental part of the diet.

The mean number of plant species identified per jackrabbit stomach was significantly higher $(p<0.05)$ for those collected on rangeland (7.2 species per stomach) and near potato fields (8.8) than for those collected near barley (5.7) or crested wheatgrass (3.7). The mean number of plant species per stomach was also significantly higher $(p<0.05)$ for jackrabbits collected near barley than for those collected near crested wheatgrass. There was a $43 \%$ similarity between the diet and the plant composition of the habitat of jackrab- 
Table 1. Number of stomachs examined (N), mean number of plant species per stomach, mean percentage of crop in diet, and resulting preference index of jackrabbits collected near four crop areas during April, June, and August 1972.

\begin{tabular}{|c|c|c|c|c|c|c|c|c|c|c|c|c|}
\hline \multirow[b]{2}{*}{ Crop area } & \multicolumn{4}{|c|}{ April } & \multicolumn{4}{|c|}{ June } & \multicolumn{4}{|c|}{ August } \\
\hline & $\mathbf{N}$ & $\begin{array}{c}\text { Species } \\
\text { per } \\
\text { stomach }\end{array}$ & $\begin{array}{c}\% \text { of } \\
\text { crop in } \\
\text { diet }\end{array}$ & $\begin{array}{c}\text { Pref. } \\
\text { index }\end{array}$ & $\mathrm{N}$ & $\begin{array}{c}\text { Species } \\
\text { per } \\
\text { stomach }\end{array}$ & $\begin{array}{c}\% \text { of } \\
\text { crop in } \\
\text { diet }\end{array}$ & $\begin{array}{c}\text { Pref. } \\
\text { index }\end{array}$ & $\mathbf{N}$ & $\begin{array}{c}\text { Species } \\
\text { per } \\
\text { stomach }\end{array}$ & $\begin{array}{c}\% \text { of } \\
\text { crop in } \\
\text { diet }\end{array}$ & $\begin{array}{l}\text { Pref. } \\
\text { index }\end{array}$ \\
\hline Crested wheatgrass & 12 & 5.5 & 23.1 & 4.4 & 11 & 3.4 & 70.0 & 4.2 & 12 & 2.2 & 80.0 & 6.5 \\
\hline Barley & 4 & 7.5 & 16.1 & 0.3 & 4 & 5.0 & 45.2 & 0.9 & 6 & 6.2 & 9.7 & 0.2 \\
\hline Barley and alfalfa & 9 & 5.8 & & & 8 & 5.0 & & & 6 & 5.5 & & \\
\hline Barley & & & 47.9 & 1.2 & & & 75.8 & 2.3 & & & 36.9 & 1.8 \\
\hline Alfalfa & & & 0.6 & 0.1 & & & 1.7 & 0.2 & & & 16.9 & 0.7 \\
\hline Potato & a & & & & 5 & 7.4 & 19.0 & 0.4 & 12 & 9.3 & 17.0 & 0.3 \\
\hline
\end{tabular}

a Crop not present in April.

bits collected on the rangeland area. The similarity indexes for the four crop areas were: crested wheatgrass, $32.6 \%$; barley, $51.9 \%$; barley and alfalfa, $55.9 \%$; and potatoes, $34.7 \%$.

\section{Discussion}

Several earlier diet studies conducted on rangeland (Arnold 1942; Lechleitner 1958; and Sparks 1968) indicated that jackrabbits preferred forbs over grasses when both were available. However, our rangeland data indicate that plant phenology was the major factor in food selection. Although we found forbs and grasses available in equal amounts (Table 2), grasses were dominant in the diet in the spring and forbs and shrubs were dominant in the fall. Jackrabbits normally fed on plants in the pre-or early reproductive stage of development. A few plants in the seed stage, particularly

Table 2. Average plant composition (\%) of rangeland and of diet of black-tailed jackrabbits collected on rangeland in Idaho. Some plants were not detected in the transects but formed a small part of the local flora and appeared in the diet.

\begin{tabular}{|c|c|c|c|c|c|c|}
\hline & \multicolumn{3}{|c|}{$\%$ plant composition } & \multicolumn{3}{|c|}{$\%$ composition of diet } \\
\hline & April & June & August & $\begin{array}{c}\text { April } \\
(\mathrm{N}=11)\end{array}$ & $\begin{array}{c}\text { June } \\
(\mathrm{N}=12)\end{array}$ & $\begin{array}{c}\text { August } \\
(\mathrm{N}=6)\end{array}$ \\
\hline \multicolumn{7}{|l|}{ Grasses } \\
\hline Agropyron desertorum & & & & & 0.2 & \\
\hline Agropyron spicatum & & 0.7 & 0.5 & & & \\
\hline Bromus tectorum & 18.4 & 21.5 & 20.5 & 45.4 & 33.7 & 3.4 \\
\hline Elymus cinereus & & & & & 1.4 & 7.1 \\
\hline Festuca octoflora & & & & 7.9 & 0.3 & $T$ \\
\hline Hordeum vulgare & & & & 10.8 & & \\
\hline Oryzopsis hymenoides & & & & 0.3 & $T$ & 0.1 \\
\hline Poa secunda & 30.6 & 24.3 & 23.5 & 18.5 & 0.2 & $\mathrm{~T}$ \\
\hline Sitanion hystrix & 0.4 & 6.1 & 4.3 & 2.0 & 8.2 & 0.4 \\
\hline \multicolumn{7}{|l|}{ Stipa comata } \\
\hline Stipa thurberiana & & 0.3 & 0.2 & 0.4 & & $\mathrm{~T}$ \\
\hline Total grass: & 49.4 & 52.9 & 49.0 & 85.3 & 44.0 & 11.0 \\
\hline \multicolumn{7}{|l|}{ Forbs and shrubs } \\
\hline Aletes sp. & & & & $\mathrm{T}$ & 0.6 & \\
\hline Allium acuminatum & 0.9 & & & & & \\
\hline Amaranthus graecizans & & & & & & 8.0 \\
\hline Antennaria sp. & & & & & 0.6 & 0.3 \\
\hline Artemisia tridentata & 15.1 & 23.3 & 33.4 & 6.4 & 15.6 & 21.2 \\
\hline Astragalus sp. & 0.2 & & & & 0.2 & \\
\hline Chrysothamnus nauseosus & 0.2 & 0.8 & 1.0 & $\mathrm{~T}$ & & 7.2 \\
\hline Cryptantha sp. & & 3.2 & 1.3 & 0.9 & 19.0 & 0.6 \\
\hline Descurainia pinnata & 8.9 & 7.8 & 4.0 & 2.5 & 2.2 & 12.4 \\
\hline Marrubium vulgare & & & & 0.3 & 1.8 & $T$ \\
\hline Medicago sativa & & & & 0.1 & 0.5 & \\
\hline Mentzelia albicaulis & 1.8 & & & & 1.0 & $\mathrm{~T}$ \\
\hline Phlox sp. & & 1.0 & & & & \\
\hline Plantago sp. & 2.0 & 5.5 & 9.2 & $\mathrm{~T}$ & & \\
\hline Salsola kali & 0.4 & 0.5 & 0.8 & $\mathrm{~T}$ & $\mathrm{~T}$ & 21.2 \\
\hline Sisymbrium altissimum & & 1.5 & 1.3 & & 2.5 & 0.2 \\
\hline Stellaria sp. & 2.7 & 0.3 & & $\mathrm{~T}$ & & $\mathrm{~T}$ \\
\hline Verbena sp. & & & & & $\mathrm{T}$ & $\mathbf{T}$ \\
\hline Grimmia sp. & 18.4 & 2.5 & & & & \\
\hline Total forbs: & 50.6 & 47.1 & 51.0 & 10.2 & 44.0 & 71.1 \\
\hline Unidentified: & & 0.7 & & 4.5 & 12.0 & 17.9 \\
\hline
\end{tabular}




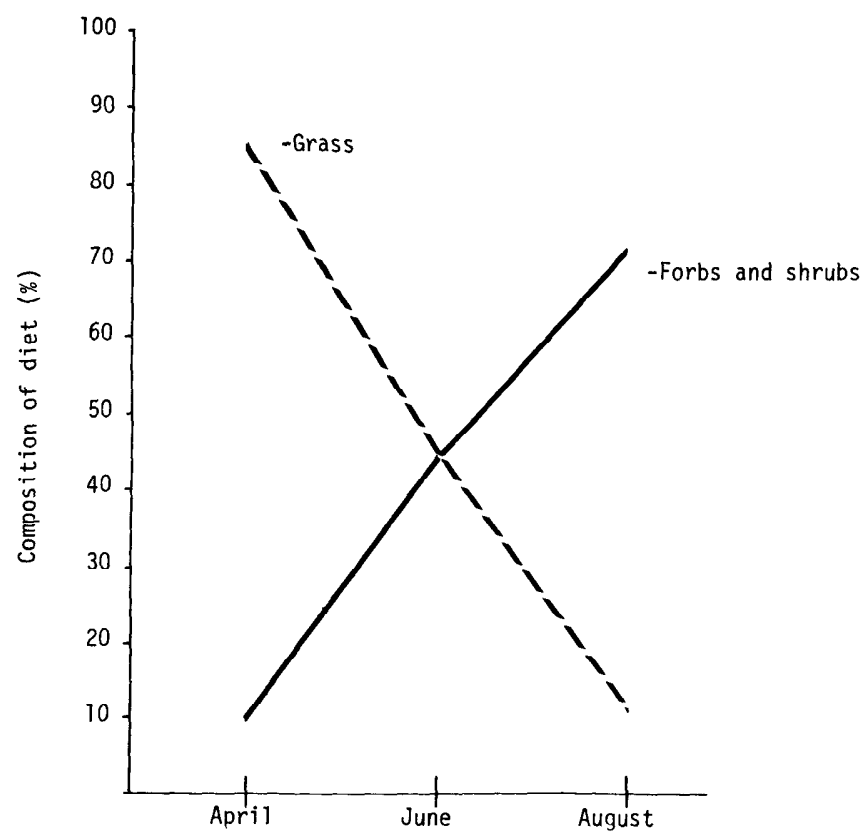

Fig. 2. Percent composition of grass and of forbs and shrubs in the diet of black-tailed jackrabbits collected during spring and summer on Idaho rangeland. Grass made up $49.4 \%$ of the habitat vegetation in April, $52.9 \%$ in June, and $49.0 \%$ in August.

crested wheatgrass, were important at certain times of the year. Our data on rangeland diets agree with those of Sparks (1968) and Flinders and Hansen (1972), who found that jackrabbits preferred grasses in spring and early summer but preferred forbs during late summer and fall. Sparks (1968) also found that phenology was important in influencing food preferences.

Availability also influenced plant selection in this study, as indicated by the high similarity (43\% on the rangeland and between $33 \%$ and $56 \%$ on the crop areas) between plant composition in the jackrabbit habitat and diet. Flinders and Hansen (1972) found only a $29 \%$ similarity between blacktailed jackrabbit annual diet and habitat on Colorado rangeland. The difference in these similarity values may reflect our lack of data on winter diet or it may indicate that jackrabbits are more efficient in utilizing their habitat in Idaho than in Colorado.

According to Currie (1963), big sagebrush was used by Utah jackrabbits only when it was dormant. However, Orr (1940) found that California jackrabbits were living almost entirely on sagebrush. In our study, big sagcbrush was eaten throughout the spring and summer and made up $14 \%$ of the diet; the greatest use occurred in August ( $21 \%$ of the diet). We found pigweed and Russian thistle to be important diet items in August. Reigel (1941) and Brown (1947) also found pigweed to be important in the jackrabbit diet but considered Russian thistle an emergency food eaten only when other food was not available.

When available to jackrabbits, cultivated crops were a large part of the spring and summer jackrabbit diet. Cultivated areas therefore supported much higher jackrabbit populations than rangeland. Crested wheatgrass is a highly preferred jackrabbit food and barley is a preferred food in some instances. Jackrabbits collected near crested wheatgrass, barley, or mixed barley and alfalfa fields ate significantly fewer other plant species than those collected near potatoes or on rangeland, indicating that jackrabbits were eating barley and crested wheatgrass to the exclusion of other plant species available in the same area. Jackrabbit densities corresponded to their utilization of crops, being highest near the mixed barley and alfalfa and crested wheatgrass fields. Potatoes were not a highly preferred food by jackrabbits, nor were jackrabbit densities as high on the potato areas as on the barley and alfalfa or crested wheatgrass areas. This finding is supported by Hegdal's (1974, unpublished) survey, which showed that potatoes did not suffer major damage from jackrabbits in any western state.

Cultivated crops adjacent to rangeland are particularly vulnerable to damage by jackrabbits because the rangeland provides daytime resting areas from which jackrabbits travel at night to forage in the crops. In cultivated areas adjacent to rangeland, damage might be reduced by planting a less preferred crop like potatoes as a buffer between the rangeland and the highly preferred crops like barley and crested wheatgrass. Potatoes would make a good buffer crop for two reasons. First, they are not a preferred food and are more resistant to jackrabbit damage than other crops. Second, jackrabbits forage most heavily on the edge of a crop that borders the rangeland. Therefore, planting potatoes as a buffer strip between the rangeland and more palatable crops should decrease the probability that jackrabbits will reach these other crops.

\section{Literature Cited}

Arnold, J.F. 1942. Forage consumption and preferences of experimentally fed Arizona and antelope jackrabbits. Univ. Arizona. Agr. Exp. Sta. Tech. Bull. No. 98. p. 51-86.

Bronson, F.H., and O.W. Tiemeier. 1958. Notes on crop damage by jackrabbits. Trans. Kansas Acad. Sci. 61: 226-229.

Brown, H.L. 1947. Why has the white-tailed jackrabbit (Lepus townsendii campanius Hollister) become scarce in Kansas? Trans. Kansas. Acad. Sci. 49: 455-456.

Carter, F.L. 1939. A study in jackrabbit shifts range in western Kansas. Trans. Kansas Acad. Sci. 42: 431-435.

Currie, P.o. 1963. Food habits of the blacktailed jackrabbit Lepus californicus) and forage competition between jackrabbits and domestic livestock on native range in northwestern Utah. Ph.D. Thesis. Utah State Univ., Logan. 87 p.

Currie, P.O., and D.L. Goodwin. 1966. Consumption of forage by blacktailed jackrabbits on salt-desert ranges of Utah. J. Wildl. Manage. 30: 304-311.

Evans, R.A., and R.M. Love. 1957. The step-point method of sampling - a practical tool in range research. J. Range Manage. 10: 208-212.

Fagerstone, K.A., H.P. Tietjen, and G.K. LaVoie. 1977. Effects of range treatment with 2,4-D on prairie dog diet. J. Range Manage. 30: 57-60.

Fautin, R.W. 1946. Biotic communities of the northern desert shrub biome in western Utah. Ecol. Monogr. 16: 251-310.

Flinders, J.T., and R.M. Hansen. 1972. Diets and habitats of jackrabbits in northeastern Colorado. Colorado State Univ. Range Sci. Dep. Sci. Ser. No. $12.29 \mathrm{p}$.

Hayden, P. 1966. Food habits of black-tailed jack rabbits in southern Nevada. J. Mammal. 47: 42-45.

Janson, R.G. 1947. A survey of the native rabbits of Utah with reference to their classification, distribution, life histories and ecology. MS Thesis. Utah State Agr. Coll., Logan. 103 p.

Kramer, C.Y. 1956. Extension of multiple range tests to group means with unequal numbers of replications. Biometrics 12: 307-310.

Lechleitner, R.R. 1958. Certain aspects of behavior of the black-tailed jack rabbit. Amer. Midl. Natur. 60: 145-155.

Lindt, J.H. 1965. Tomato seedlings damage by insects and wildlife. Calif. Tomato Grower 8: 7.

Nelson, E.W. 1930. Wild animals of North America; intimate studies of big and little creatures of the mammal kingdom. The National Geographic Society, Washington, D.C. 254 p.

Oosting, H.J. 1956. The Study of Plant Communities. 2nd ed. W.H. Freeman and Co., San Francisco. 440 p.

Orr, R.T. 1940. The rabbits of California. California Acad. Sci. Occasional Papers No. 19. 227 p. 
Riegel, A. 1941. Some observations of the food coactions of rabbits in western Kansas during periods of stress. Trans. Kansas Acad. Sci. 45: 369-375.

Schwartz, C.W., and E.R. Schwartz. 1959. The wild mammals of Missouri. Univ. of Missouri Press and Mo. Conserv. Comm. 341 p.

Sparks, D.R. 1968. Diet of black-tailed jackrabbits on sandhill rangeland in Colorado. J. Range Manage. 21: 203-208.
Tiemeier, O.W. 1965. The black-tailed jack rabbit in Kansas. I. Bionomics. Kansas State Univ. Agr. Exp. Sta. Tech. Bull. 140. p. 5-37.

Vorhies, C.T., and W.P. Taylor. 1933. The life histories and ecology of jack rabbits, Lepus alleni and Lepus californicus spp., in relation to grazing in Arizona. Univ. of Arizona Agr. Exp. Sta. Tech. Bull. No. 49. p. 67-587. 